\title{
Article
}

\section{Influence of a Dissection Video Clip on Anxiety, Affect, and Self-Efficacy in Educational Dissection: A Treatment Study}

\author{
Christoph Randler, Eda Demirhan, ${ }^{\dagger}$ Peter Wüst-Ackermann, ${ }^{*}$ and Inga H. Desch ${ }^{*}$
}

\author{
${ }^{*}$ Department of Biology, University of Education Heidelberg, D-69121 Heidelberg, Germany; ${ }^{\dagger}$ Department of \\ Special Education, Sakarya University, Sakarya 54300, Turkey
}

Submitted July 6, 2015; Revised November 7, 2015; Accepted November 7, 2015

Monitoring Editor: Eric Chudler

\begin{abstract}
In science education, dissections of animals are an integral part of teaching, but they often evoke negative emotions. We aimed at reducing negative emotions (anxiety, negative affect [NA]) and increasing positive affect (PA) and self-efficacy by an experimental intervention using a predissection video to instruct students about fish dissection. We compared this treatment with another group that watched a life history video about the fish. The participants were 135 students studying to become biology teachers. Seventy received the treatment with the dissection video, and 65 viewed the life history video. We applied a pre/posttest treatment-comparison design and used the Positive and Negative Affect Schedule (PANAS), the State-Trait-Anxiety Inventory for State (STAI-S), and a self-efficacy measure three times: before the lesson (pretest), after the film treatment (posttest 1), and after the dissection (posttest 2). The dissection film group scored higher in PA, NA, and state anxiety (STAI-S) after the dissection video treatment and higher in self-efficacy after the dissection. The life history group showed no differences between the pretest and posttest 1 . The dissection film has clear benefits-increasing PA and self-efficacy_that come at the cost of higher NA and higher STAI-S.
\end{abstract}

\section{INTRODUCTION}

In biology, veterinary, and medical education, dissections of animals and humans are an integral part of teaching and learning and help students learn the scientific content and strengthen their methodological skills. Furthermore, dissection is a valuable tool that motivates students. This can lead them to reinforce their knowledge of anatomy and morphology (Berman, 1984; Orlans, 1988). Therefore, we aimed at reducing negative emotions and increasing positive emotions and self-efficacy through an experimental intervention. We used a predissection video to instruct students. This video

CBE Life Sci Educ March 1, 2016 15:ar1

DOI:10.1187/cbe.15-07-0144

Address correspondence to: Christoph Randler (randler@ph -heidelberg.de).

(C) 2016 C. Randler et al. CBE-Life Sciences Education (C) 2016 The American Society for Cell Biology. This article is distributed by The American Society for Cell Biology under license from the author(s). It is available to the public under an Attribution-Noncommercial-Share Alike 3.0 Unported Creative Commons License (http://creativecommons.org/licenses/by-nc-sa/3.0).

"ASCB®" and "The American Society for Cell Biology ${ }^{\circledR}$ " are registered trademarks of The American Society for Cell Biology. was designed to prepare students for the dissection and showed the dissection of a trout. We compared this group of students with a treatment group who received a video clip of the life history of the trout (the species that was dissected). Our research was informed by studies showing that information could reduce anxiety in medical education.

\section{The Role of Emotions in Learning}

Pekrun et al. (2011) defined emotions as a set of interrelated psychological processes (affective, cognitive, physiological, and motivational). Emotions have an effect on students' cognitive processes and performance (Pekrun et al., 2002) and can be mainly categorized as positive emotions (e.g., relief, hope, pride) and negative emotions (e.g., anger, envy, sadness; Linnenbrink and Pintrich, 2002; Pekrun et al., 2011). In biology education, disgust, fear, and anxiety are important emotions that can be task related because of the specificity of biology, namely the work with dissection (Holstermann et al., 2009; Randler et al., 2012a) or when encountering living animals (Hummel and Randler, 2012; Randler et al., 2012b).

Anxiety is conceptualized as state and trait anxiety. Spielberger et al. (1970) developed a scale called the StateTrait Anxiety Inventory (STAI; Spielberger et al., 1970, 1976) that is used all over the world (Marteau and Bekker, 1992; 
Barnes et al., 2002). Pekrun et al. (2002) found inverse correlations between interest on the one side and negative emotions like anger and anxiety on the other, suggesting that negative emotions lower interest. In elementary students, Randler et al. (2005) found that children who were less anxious for amphibians had significantly higher knowledge scores than more anxious ones. Randler and colleagues (2012b, 2013) found a negative effect of anxiety on motivation, interest, and achievement during a dissection task. In light of these studies, reducing anxiety is important in mastering a task.

The Positive and Negative Affect Schedule (PANAS) is another means to measure emotions. It was developed to provide a reliable estimate of two broad and largely independent factors implicated in emotional experience: positive and negative affect (PA and NA; Watson et al., 1988; Rossi and Pourtois, 2012). While PA represents the extent to which an individual experiences pleasurable engagement, NA represents subjective distress and unpleasant engagement with the environment (Watson and Clark, 1984). The PANAS is widely used by psychologists and in medical settings. In terms of education, it was used especially for defining educational programs' emotional outcomes, and it has been used with children and college students in many settings (Cassady and Johnson, 2002; Pajares, 2002; Lane et al., 2004; Koutsis et al., 2007; Alivernini and Lucidi, 2011). To our knowledge, the PANAS has not been used in the context of dissection. However, as dissection is also a challenging emotional task, using the PANAS to measure the effect of treatments is appropriate.

Self-efficacy generally is associated with an individuals belief in his or her own proficiency to gain the targeted goals in a certain domain (Bandura, 1994). More simply, self-efficacy is a person's belief in his or her ability to influence events that affect his or her life (Bandura, 1994). Individuals' self-efficacy beliefs can influence cognitive, motivational, and affective processes (Bandura and Locke, 2003). Some studies argue that perceived confidence in carrying out a given task (e.g., mastering biological content and processes) will predict acquisition of skills and subsequent behavior (Baldwin et al., 1999). Concerning treatments and interventions in science education, Holstermann et al. (2009) suggested that self-efficacy has an influence during a dissection task, with a higher perceived self-efficacy leading to a better performance; these authors also noted that self-efficacy itself was negatively influenced by disgust. Students who felt more disgust saw themselves as less effective when mastering the dissection task; in addition, higher disgust was related to lower interest (Holstermann et al., 2009). Because of the important influence of self-efficacy in learning processes, we wanted to test whether the treatments would have an influence on self-efficacy.

\section{Anxiety, Stress, and Emotions in Dissection}

Medical students report a variety of feelings and (ambivalent) emotions before their first cadaver dissection, for example, excitement but also anxiety and stress (Oyeyipo and Falana, 2012). Horne et al. (1990) noticed in their survey study that students expressed a desire for greater preparation before the first cadaver dissection, particularly through more discussion of the experience with the anatomy staff. The authors suggested improving the preparation for coping with human dissection (Horne et al., 1990). As a general pattern in most studies, participants felt lower anxiety after the dissection than before (Arraez-Aybar et al., 2004; Randler et al., 2012b).

Means to reduce negative emotions such as anxiety, disgust, and NA have been applied in both human cadaver and animal dissection situations. In medical students, anxiety and stress decreased from the first to the last dissection day in students who were well supported by friends, family, or colleagues and in those who held a funeral ceremony for the dissected cadavers (Boeckers et al., 2010). This shows that some kind of emotional or psychological support is necessary and would aid and support students during their first dissections. The authors further suggested a systematic approach to better familiarize medical students before their first dissection. Williams et al. (2014) found that naming cadavers is extremely prevalent among medical students ( $\sim 68 \%$ did this) and that these inventive names can be seen as a beneficial coping mechanism. These studies were mainly descriptive.

Some experimental experience about the reduction of anxiety by viewing video clips comes from medical education. Instructive videos about the dissection room helped to reduce anxiety (Arráez-Aybar et al., 2004). Arráez-Aybar et al. (2004) also found that a repeated or gradual exposure before the first dissection task reduced the participants' anxiety. The advantage of the study was that these authors applied a control group in an experimental design (Arráez-Aybar et al., 2004). Similarly, Casado et al. (2012) applied an intervention. These authors used audiovisual material that contained real images of dissected human cadavers. This significantly reduced the anxiety of the participants, especially when it was shown immediately before the dissection. However, video clips have not been used in science learning and instruction to reduce anxiety and influence affect.

\section{Dissection in Education}

Dissection is an essential part of biology and medical education (Kinzie et al., 1993). The National Association of Biology Teachers (2008) supports dissection, although it has alternatives, such as video instruction or virtual dissection. In addition, the National Science Teachers Association (2005) supports dissection in science education to help students to develop observation and comparison skills, discover the structures of specific organisms, and realize the complexity of life. Still, several researchers claimed that dissection is a waste of animal life (DeRosa, 1986) and can lead to psychological trauma in students (DeRosa, 1986). In addition, ethical and environmental concerns surrounding the killing of animals (People for the Ethical Treatment of Animals, 2004) and ignoring animal welfare standards (Bishop and Nolen, 2001; Hug, 2008; Oakley, 2009) create a controversy. Virtual alternatives (such as virtual dissection simulations, three-dimensional models, palatinate specimens, videos, etc.) can be equivalent for gaining knowledge about anatomy and physiology and are sometimes superior to real dissection in middle and high school (Youngblut, 2001; Kopec, 2002; Maloney, 2005; Montgomery, 2008; Lalley et al., 2010). However, dissection alternatives (model, videos, or diagrams) cannot provide the same kind of learning when compared with real dissection (Offner, 1993), because students cannot 
acquire practical skills (DeVilliers and Monk, 2005). Dissection is a valuable tool that motivates students and can also help them reinforce their understanding of anatomy and morphology (Hoskins, 1979; Berman, 1984; Igelstud, 1986; Orlans, 1988). In an American survey, 75-79\% of the biology teachers questioned used dissection to teach biology in their classes, and only $31.4 \%$ believed that alternatives were as good as dissections because dissections foster methodological skills (King et al., 2004). Demirhan (2014) showed that $75 \%$ of prospective science teachers preferred dissection to alternatives, even though dissection can cause negative feelings. Because dissection remains a valuable tool in teaching science, reducing negative emotions is important.

\section{Current Study}

In this study, we applied an informative video showing the dissection of a fish (species: trout) to enhance positive emotions and reduce anxiety. First, we hypothesized that an informational video would reduce anxiety and NA, as was found in previous work with medical students (Arráez-Aybar et al., 2004). Second, we thought that the video would increase PA and self-efficacy. To this end, we compared the dissection film treatment group with a group who viewed a video about the life history of the fish. We compared the groups based on three tests: before the lesson (pretest), after the film treatment (posttest 1), and after the dissection (posttest 2).

\section{METHODS}

\section{Participants and Data Collection}

The participants of the Winter terms 2013-2014 were students studying to become biology teachers at the University of Education Heidelberg. The first semester starts with a zoology course, and dissection is an integral part of this course. The students were assigned to one of four course sections that are identical in content and take place on the same day. We offer multiple sections to allow smaller class sizes. One hundred thirty-five students (113 females, 21 males, 1 unspecified) participated in the study. Seventy participants received the treatment with the dissection video, and 65 viewed the life history video. The trout were not present in the dissection laboratory while the students watched the video and completed the pretest, and students were prevented from seeing or smelling the fish, because this could elicit negative emotions.

The monies for purchasing the trout came from the university's Qualitätsfondsmittel Lehre, which allows students to decide which projects will receive money. We regularly evaluate this process to give the committee and our students direct feedback about the results, and at this time, the university's Ethik-Kommission (comparable to an institutional review board) decided that a formal application was not necessary. However, we had to follow the internal guidelines of this committee (e.g., student participation was unpaid, voluntary, anonymous, not used for grading/ marking). The students were instructed that we use questionnaires to assess our teaching and to improve it. Further, we obtained informed consent and reported the results as soon as possible to the students during a lecture and by making the information available on the university's learning management system. Table 1 shows the outline of the study with the three measurements.

\section{Experimental Procedures}

The treatment was assigned per course section. That is, we randomly selected the courses that received 1) the dissection video or 2) the life history video. The students had no choice, and the sample therefore was not self-selected. Immediately after the students had arrived and settled in the dissection laboratory, the pretest was applied. After the pretest, we showed a video about the trout. One treatment group received a pre-existing film about the life history of the trout. This film is regularly sold to schools and universities by a commercial seller and is designed for teaching in schools and universities (FWU-Medien Institut der Länder, order/identification no.: FWU 46 02344). In this film, the life cycle during the year is shown (feeding, predator-prey relationships, behavior, reproduction). This treatment group served as a comparison group. The other treatment group viewed a video about the dissection of the trout. This film has been developed to demonstrate the task of dissecting trout and matched the goals of our curriculum. The film can be found on www.youtube.com/watch?v=O-U7KwGMJ1o. Both video films were about the same length (life history video: $10 \mathrm{~min}$; dissection video: $12 \mathrm{~min}$ ). After the films had been shown, posttest 1 was administered. Then, both groups dissected the trout. Posttest 2 test was applied immediately after dissection.

\section{Measures}

Cronbach's alpha was used as a measure of internal consistency (reliability). The alpha was calculated based on this present sample.

\section{Self-Efficacy Scale}

The self-efficacy scale was self-developed and based on the suggestions of Bandura (2006). The scale was designed to measure the self-efficacy and self-confidence of the students, specifically in mastering the dissection task. Wording was developed based on previous, unpublished, qualitative

Table 1. Overview of the study design

\begin{tabular}{lcccc}
\hline \multicolumn{1}{c}{ Pretest $(5 \mathrm{~min})$} & Treatment $(10 \mathrm{~min})$ & Posttest $1(5 \mathrm{~min})$ & Lesson $(75 \mathrm{~min})$ & Posttest $2(5 \mathrm{~min})$ \\
\hline STAI-S & Dissection film $(N=70)$ & STAI-S & Dissection task (identical in & STAI-S \\
PANAS & vs. & PANAS & Poth treatments $)$ & PANAS \\
Self-efficacy & Life history film $(N=65)$ & Self-efficacy & & Self-efficacy \\
\hline
\end{tabular}


Table 2. The self-efficacy measurement specifically developed for the trout dissection

\begin{tabular}{|c|c|c|c|c|c|c|c|}
\hline \multirow[b]{2}{*}{ German wording } & \multirow[b]{2}{*}{ English translation } & \multicolumn{2}{|c|}{ Pretest } & \multicolumn{2}{|c|}{ Posttest 1} & \multicolumn{2}{|c|}{ Posttest 2} \\
\hline & & $\begin{array}{l}\text { Corrected } \\
\text { item-scale } \\
\text { correlation }\end{array}$ & $\begin{array}{c}\text { Cronbach's } \\
\text { alpha if item } \\
\text { deleted }\end{array}$ & $\begin{array}{l}\text { Corrected } \\
\text { item-scale } \\
\text { correlation }\end{array}$ & $\begin{array}{c}\text { Cronbach's } \\
\text { alpha if item } \\
\text { deleted }\end{array}$ & $\begin{array}{l}\text { Corrected } \\
\text { item-scale } \\
\text { correlation }\end{array}$ & $\begin{array}{c}\text { Cronbach's } \\
\text { alpha if item } \\
\text { deleted }\end{array}$ \\
\hline $\begin{array}{l}\text { Ich werde auch die schwi- } \\
\text { erigen Aufgaben bei der } \\
\text { Forellensektion lösen. }\end{array}$ & $\begin{array}{l}\text { I will solve the difficult } \\
\text { tasks of the dissection. }\end{array}$ & 0.47 & 0.57 & 0.59 & 0.61 & 0.64 & 0.66 \\
\hline $\begin{array}{l}\text { Ich mache mir Sorgen, die } \\
\text { Organe bei der Präparation } \\
\text { zu beschädigen. }\end{array}$ & $\begin{array}{l}\text { I have some doubts that I } \\
\text { may destroy the organs } \\
\text { during the dissection. }\end{array}$ & 0.17 & 0.76 & 0.13 & 0.82 & 0.45 & 0.74 \\
\hline $\begin{array}{l}\text { Ich werde die Präparation } \\
\text { meistern. }\end{array}$ & I will master the dissection. & 0.51 & 0.55 & 0.64 & 0.59 & 0.55 & 0.70 \\
\hline $\begin{array}{l}\text { Ich werde alle Organe } \\
\text { erkennen und benennen } \\
\text { können. }\end{array}$ & $\begin{array}{l}\text { I will be able to identify and } \\
\text { label all organs correctly. }\end{array}$ & 0.47 & 0.57 & 0.50 & 0.65 & 0.38 & 0.76 \\
\hline $\begin{array}{l}\text { Ich gehe davon aus, die } \\
\text { Schnitte alle korrekt zu } \\
\text { setzen. }\end{array}$ & $\begin{array}{l}\text { I will be able to make all the } \\
\text { cuts correctly. }\end{array}$ & 0.55 & 0.53 & 0.61 & 0.60 & 0.60 & 0.68 \\
\hline
\end{tabular}

research (C.R. and P.W.-A., unpublished data from 2009) about the thoughts and concerns of the students in relation to dissecting fish. For example, some students reported that they are afraid to destroy the internal organs of the fish or that they are afraid that time will run out. Additional information was gained by a qualitative analysis from a fish dissection study published by Randler et al. (2016). In their study, students mentioned the handling of the trout or their fear of destroying fish organs during the dissection. The scales were constructed as a prospective scale for pretest and posttest 1 , because these tests were applied before the dissection (e.g., "I will be able to label all organs correctly"). Posttest 2 used the same items but in retrospect, because it was applied after the dissection (e.g., "I was able to label all organs correctly"). Details of the item wording are given in Table 2. Cronbach's alpha for the standardized items was 0.70 for pretest, 0.73 for posttest 1 , and 0.75 for posttest 2 ; one item was reverse coded in the prospective version (pretest and posttest 1), and none were reverse coded for the retrospective form (posttest 2). The items were rated from 1 to 5 from "fully disagree" to "fully agree" (see Table 2 for item details).

\section{PANAS}

The PANAS has been widely used to investigate changes in PA or NA states in healthy volunteers, mainly in experimental contexts aimed at either up- or down-regulating stress responses (Rossi and Pourtois, 2012). The PANAS was developed by Watson et al. (1988) and was adapted into German by Krohne et al. (1996). In this study, we used the international short version of the PANAS, which was published by Thompson (2007). The German wording of the items was extracted from Krohne et al. (1996). The scale is composed of 10 Likert-type items a five-point Likert-type scale (ranging from $1=$ never, to $5=$ always). It contains five items to measure PA and five items to measure NA. Cronbach's alpha of PA was for 0.78 for pretest, 0.83 for posttest 1 , and 0.80 for posttest 2. Similarly, for NA, it was 0.61 for pretest, 0.66 for posttest 1 , and 0.79 for posttest 2 .

\section{STAI}

State anxiety is measured by the State-Trait-Anxiety Inventory (STAI; Spielberger et al., 1970, 1976). The STAI is a brief self-report scale designed to measure and differentiate between anxiety as a trait and a state (Spielberger et al., 1970). State anxiety fluctuates and is a function of the stressors on an individual. State anxiety should be low in nonstressful situations (Barnes et al., 2002). State anxiety was measured with a scale (20 items) that is sensitive toward changes (STAI-S; Laux et al., 1981). The items are rated on a four-point Likert scale; 10 items are positively coded, and 10 items are negatively coded. Students rated how they felt at a particular moment (e.g., calm, tense). The reliability of the state anxiety scale was high in the present sample (pretest: $\alpha=0.91$; posttest 1: $\alpha=0.92$; posttest 2: $\alpha=0.86$ ).

\section{Dissection Task}

The following procedure was applied: the students took the pretest, watched the video, took the first posttest (posttest 1), dissected the trout, and then took the second posttest (posttest 2). The lesson lasted $100 \mathrm{~min}$. In the first $10 \mathrm{~min}$, the students watched a video about the trout (treatment: life history video vs. dissection video), after which a lecturer explained the dissection procedure and gave some background information about the anatomy and internal and external structures $(30 \mathrm{~min}$ ) of the rainbow trout (Oncorhynchus mykiss, Walbaum, 1792; family Salmonidae). The same person, who is an experienced university teacher, carried out lectures for all students. The trout were bought from a commercial stock. Afterward, the students dissected the trout in groups (usually two people in a group).

\section{Statistical Analyses}

We used paired $t$ tests and a series of multivariate general linear models with covariance (earlier known as MANCOVA) and subsequent univariate models for every set of variables. For example, for state anxiety (STAI-S), we used pretest state anxiety as covariate and posttest 1 and posttest 2 
Table 3. Univariate general linear models with PA as dependent measures (posttest 1, posttest 2), pretest scores of PA as covariate, and treatment (dissection film vs. life history film) as fixed factor

\begin{tabular}{|c|c|c|c|c|c|c|c|}
\hline & \multicolumn{4}{|c|}{ Posttest 1} & \multicolumn{3}{|c|}{ Posttest 2} \\
\hline & $d f$ & $F$ & $p$ & $\eta^{2}$ & $F$ & $p$ & $\eta^{2}$ \\
\hline $\begin{array}{c}\text { Corrected } \\
\text { model }\end{array}$ & 2 & 61.79 & $<0.001$ & 0.48 & 38.46 & $<0.001$ & 0.37 \\
\hline Intercept & 1 & 8.54 & $<0.005$ & 0.06 & 29.44 & $<0.001$ & 0.18 \\
\hline $\begin{array}{c}\text { PA pretest } \\
\text { scores }\end{array}$ & 1 & 118.73 & $<0.001$ & 0.47 & 76.62 & $<0.001$ & 0.37 \\
\hline Treatment & 1 & 7.90 & 0.006 & 0.06 & 0.00 & 0.957 & 0.00 \\
\hline
\end{tabular}

as dependent variables. Treatment (dissection video vs. life history video) was used as fixed factor. Similar calculations were used for PA, NA, and self-efficacy. SPSS 22.0 was used (IBM, German version, München).

\section{RESULTS}

Concerning PA, we found a significant influence of prior PA values on the subsequent measures of PA (Table 3). In addition, the treatment led to a significant difference in posttest 1 but not in posttest 2 (Table 3). After the treatment, PA was higher in posttest 1 in the dissection film group $(p=0.006)$. This explained $5.6 \%$ of the variances. No difference could be found in posttest 2. Estimated marginal means (derived from the general linear model [GLM]) of PA after the film treatment were $3.37 \pm 0.07$ in the dissection film group and 3.08 \pm 0.07 in the life history film group. Thus, the dissection film resulted in a higher PA.

Concerning NA, prior values significantly influenced the values in posttests 1 and 2 (Table 4 ). In addition, treatment had an influence on the posttest 1 scores, with an explained variance of $\sim 11 \%$, but it had no significant influence on posttest 2 scores. Estimated marginal means in posttest 1 for NA were $1.66 \pm 0.04$ in the dissection film group and $1.32 \pm 0.04$ in the life history film group. Thus, the dissection film resulted in a higher NA than the life history film.

Pretest scores significantly influenced state anxiety (STAI-S). Treatment showed a significant effect on STAI-S in posttest 1 , with $\sim 5 \%$ of variance explained (Table 5 ). There was no influence of treatment on posttest 2. Estimated marginal means for STAI-S were $2.12 \pm 0.03$ in the dissection film

Table 4. Univariate general linear models with NA as dependent measures (posttest 1, posttest 2), pretest scores of NA as covariate, and treatment (dissection film vs. life history film) as fixed factor

\begin{tabular}{|c|c|c|c|c|c|c|c|}
\hline & \multicolumn{4}{|c|}{ Posttest 1} & \multicolumn{3}{|c|}{ Posttest 2} \\
\hline & $d f$ & $F$ & $p$ & $\eta^{2}$ & $F$ & $p$ & $\eta^{2}$ \\
\hline $\begin{array}{c}\text { Corrected } \\
\text { model }\end{array}$ & 2 & 57.87 & $<0.001$ & 0.47 & 6.35 & 0.002 & 0.09 \\
\hline Intercept & 1 & 25.33 & $<0.001$ & 0.16 & 86.80 & $<0.001$ & 0.40 \\
\hline $\begin{array}{l}\text { NA pretest } \\
\text { scores }\end{array}$ & 1 & 90.67 & $<0.001$ & 0.41 & 12.28 & 0.001 & 0.09 \\
\hline Treatment & 1 & 16.31 & $<0.001$ & 0.11 & 0.09 & 0.767 & 0.00 \\
\hline
\end{tabular}

Table 5. Univariate general linear models with state anxiety (STAI-S) as dependent measures (posttest 1, posttest 2), pretest scores of STAI-S as covariate, and treatment (dissection film vs. life history film) as fixed factor

\begin{tabular}{|c|c|c|c|c|c|c|c|}
\hline & \multicolumn{4}{|c|}{ Posttest 1} & \multicolumn{3}{|c|}{ Posttest 2} \\
\hline & $d f$ & $F$ & $p$ & $\eta^{2}$ & $F$ & $p$ & $\eta^{2}$ \\
\hline $\begin{array}{c}\text { Corrected } \\
\text { model }\end{array}$ & 2 & 191.83 & $<0.001$ & 0.75 & 16.84 & $<0.001$ & 0.21 \\
\hline Intercept & 1 & 4.85 & $<0.05$ & 0.04 & 52.47 & $<0.001$ & 0.29 \\
\hline $\begin{array}{l}\text { STAI-S } \\
\text { pretest } \\
\text { scores }\end{array}$ & 1 & 367.51 & $<0.001$ & 0.74 & 33.65 & $<0.001$ & 0.21 \\
\hline Treatment & 1 & 6.79 & 0.010 & 0.05 & 0.31 & 0.578 & 0.00 \\
\hline
\end{tabular}

group and $2.00 \pm 0.03$ in the life history film group. Thus, the life history film group showed a lower anxiety, while in the dissection film group anxiety was higher.

Concerning self-efficacy, there was a significant effect of pretest scores on both posttests (Table 6). However, a treatment effect was significant in posttest 2, while the treatment effect in posttest 1 showed a small but insignificant effect (Table 6). Mean values of self-efficacy after the film treatment were $3.49 \pm 0.06$ in the dissection film group and $3.34 \pm 0.06$ in the life history film group. Thus, the dissection film resulted in a small but insignificant higher self-efficacy for the dissection film treatment group. However, at posttest 2 (after the dissection), students in the dissection film group reported better mastery of their dissection, and there were significant differences in self-efficacy (dissection film: $4.52 \pm 0.07$; life history film: $4.18 \pm 0.07)$.

Concerning the comparison between the pretest and posttest 1, we found significant differences in PA, NA, STAI-S, and self-efficacy; however, these changes were only significant in the dissection film group but not in the life history film group (Table 7).

\section{DISCUSSION}

The dissection film treatment had a short-term effect on all emotional variables immediately after the film (posttest 1) and a long-term effect on self-efficacy concerning mastery of the dissection task (posttest 2). Self-efficacy for mastering the

Table 6. Univariate general linear models with self-efficacy as dependent measures (posttest 1, posttest 2), pretest scores of STAI-S as covariate, and treatment (dissection film vs. life history film) as fixed factor

\begin{tabular}{|c|c|c|c|c|c|c|c|}
\hline & \multicolumn{4}{|c|}{ Posttest 1} & \multicolumn{3}{|c|}{ Posttest 2} \\
\hline & $d f$ & $F$ & $p$ & $\eta^{2}$ & $F$ & $p$ & $\eta^{2}$ \\
\hline $\begin{array}{c}\text { Corrected } \\
\text { model }\end{array}$ & 2 & 79.23 & $<0.001$ & 0.55 & 14.52 & $<0.001$ & 0.19 \\
\hline Intercept & 1 & 6.08 & 0.015 & 0.05 & 140.76 & $<0.001$ & 0.52 \\
\hline $\begin{array}{l}\text { Self- efficacy } \\
\text { pretest } \\
\text { scores }\end{array}$ & 1 & 155.59 & 0.000 & 0.55 & 17.41 & $<0.001$ & 0.12 \\
\hline Treatment & 1 & 3.05 & 0.083 & 0.02 & 11.77 & 0.001 & 0.08 \\
\hline
\end{tabular}


Table 7. Comparison of pretest scores with posttest (life history vs. dissection film) ${ }^{\mathrm{a}}$

\begin{tabular}{|c|c|c|c|c|c|c|c|c|c|c|c|c|c|c|}
\hline & \multicolumn{7}{|c|}{ Dissection film clip $(d f=69)$} & \multicolumn{7}{|c|}{ Life history film clip $(d f=64)$} \\
\hline & \multicolumn{2}{|c|}{ Pretest } & \multicolumn{2}{|c|}{ Posttest 1} & \multirow[b]{2}{*}{$\mathrm{T}$} & \multicolumn{2}{|c|}{ Posttest 2} & \multicolumn{2}{|c|}{ Pretest } & \multicolumn{2}{|c|}{ Posttest 1} & \multirow[b]{2}{*}{$\mathrm{T}$} & \multicolumn{2}{|c|}{ Posttest 2} \\
\hline & Mean & $\mathrm{SD}$ & Mean & SD & & Mean & SD & Mean & SD & Mean & SD & & Mean & SD \\
\hline Self-efficacy & 3.33 & 0.58 & 3.50 & 0.74 & $-2.676^{*}$ & 4.51 & 0.52 & 3.33 & 0.63 & 3.35 & 0.65 & $-0.470^{* *}$ & 4.15 & 0.52 \\
\hline PANAS PA & 3.11 & 0.69 & 3.34 & 0.84 & $-3.022^{*}$ & 3.43 & 0.74 & 3.18 & 0.68 & 3.11 & 0.76 & $1.020^{* *}$ & 3.48 & 0.78 \\
\hline PANAS NA & 1.40 & 0.40 & 1.59 & 0.51 & $-3.515^{*}$ & 1.16 & 0.35 & 1.32 & 0.46 & 1.29 & 0.40 & $0.895^{* *}$ & 1.13 & 0.30 \\
\hline STAI-S & 2.04 & 0.45 & 2.15 & 0.49 & $-3.234^{*}$ & 1.64 & 0.38 & 1.95 & 0.47 & 1.96 & 0.50 & $-0.406^{* *}$ & 1.65 & 0.33 \\
\hline
\end{tabular}

${ }^{\mathrm{a}}$ All changes between pretest and posttest 2 were $p<0.01$. T refers to the T-value of the T-test.

${ }^{*} p<0.01$.

${ }^{* *}$ Not significant.

task was higher in the group who had viewed the dissection film. This is an interesting and important result, because it suggests that the use of such films helps to improve the performance of the students during their dissection work. Self-efficacy was measured by self-report. In addition, further studies should use evaluations of student work (e.g., video material to assess performance, observation of dissection skills), to check whether students indeed perform better. However, Pintrich and De Groot (1990) reported a medium correlation between self-report self-efficacy and grades. Jansen et al. (2014) showed that science self-efficacy was a good predictor of current ability, suggesting that students are able to assess their performance.

Emotional variables (PA, NA, and STAI-S) were all higher in the dissection film group immediately after the film presentation (posttest 1). These results suggest that the dissection film elicits stronger and ambivalent emotional responses compared with the life history film, probably because these students are more aware of their forthcoming dissection task. Similarly, other studies also repeated such ambivalent emotions: Arráez-Aybar et al. (2004) reported that anxiety is a strong response, but also novelty. Oyeyipo and Falana (2012) reported excitement but also anxiety and stress as the most important emotional aspects. Thus, these studies indicate the ambivalent emotions and corroborate our results. The higher PA after the dissection film is important, because PA, in turn, is correlated with educational outcomes, such as intrinsic motivation, interest (Bye et al., 2007), achievement scores, and GPA (Gumora and Arsenio, 2002).

One main aim of our study, reducing student anxiety around the task of dissection, was not reached. This is in contrast to some medical studies (Arráez-Aybar et al., 2004; Casado et al., 2012). Arráez-Aybar et al. (2004) showed that a repeated or gradual exposure before the dissections reduced the participants' anxiety. They provided detailed verbal information on the situation, visits to dissecting rooms without the presence of a cadaver, and videos showing pictures of human dissections. Students in this treatment had lower anxiety. This study, therefore, differs from our, because we did not expose our students gradually, and the time spent in introducing the students to the concept was longer in their study. Second, Arráez-Aybar et al. (2004) and Casado et al. (2012) used different material and media, while in our study only a video dissection was used for information. In addi- tion, it may be related to the different populations: biology teacher students in our sample and medical students in their study. Usually, medical students know that they have to face cadaver dissection, while teacher students might not expect to do dissection.

At first glance, it seems counterintuitive that both PA and NA increased simultaneously after the dissection film. This may be due to several reasons (e.g., emotional ambivalence, see Anxiety, Stress, and Emotions in Dissection). However, the scale developers intended PA and NA to be different constructs and not the opposite ends of a continuum (Watson and Clark, 1984), rather they are considered to be two orthogonal factors (Rossi and Pourtois, 2012). Thus, an increase in both emotional affect scales is possible. The Cronbach's alpha of the NA scale was not optimal. Future studies should try to assess the reliability of this measure using other samples. In addition, attempts to improve the scale should be made. However, the correlations of PA with state anxiety (STAI-S) were medium to high (pre: 0.69, post-1: 0.72; post-2: 0.47). This adds some external validity to the PA scale.

The changes in emotional variables were only significant immediately after the treatments, thus showing a short-term effect. This clearly suggests that the videos should be applied immediately before the dissection starts and not a few days before. However, in science education, this effect has never been tested and could be a venue for future work, that is, a comparison of the time gap between viewing the dissection video and the start of the dissection might be enlightening. The short term-effect of increasing STAI-S and NA may diminish when the videos are watched one or a few days before rather than immediately before the dissection. This would encourage the use of the dissection films one or a few days before, thus ensuring that the information is available but that negative emotions have time to diminish. However, it might also influence self-efficacy, so that the positive effects of the film on self-efficacy might get lost. Therefore, future studies should try to determine the optimal time point for viewing the dissection film.

Future studies might include a control group that does not watch any of these films. However, that is a matter of experimental design: when to apply the test, and what to do during the time when the experimental groups view the video clips. Further, qualitative data from interviews and observations should be added to complement the self-report questionnaires. 


\section{CONCLUSION}

The benefits and disadvantages are clear. The dissection film has benefits in increasing PA and self-efficacy, which comes at the cost of higher NA and higher STAI-S. Therefore, such a film could be applied, especially in well-informed groups, such as medical students or biology students at the university. However, in groups with high anxiety, for example, schoolchildren, it might be better to skip the film clip or to show another film (e.g., about the life history of the organism to be dissected).

\section{ACKNOWLEDGMENTS}

We are grateful to our students for participating in this study and for their patience in completing the many questionnaires. This study was partially funded by the Qualitätsfondsmittel Lehre (for purchase of the trout). We are thankful for the very important comments of the reviewers, which helped to improve the manuscript.

\section{REFERENCES}

Alivernini F, Lucidi F (2011). Relationship between social context, self-efficacy, motivation, academic achievement, and intention to drop out of high school: a longitudinal study. J Educ Res 104, 241252.

Arráez-Aybar LA, Casado-Morales MI, Castano-Collado G (2004). Anxiety and dissection of the human cadaver: an unsolvable relationship? Anat Rec B New Anat 279, 16-23.

Baldwin JA, Ebert-May D, Burns D (1999). The development of a college biology self-efficacy instrument for nonmajors. Sci Educ 83, 397-408.

Bandura A (1994). Self-Efficacy, New York: Wiley.

Bandura A (2006). Guide for constructing self-efficacy scales. In: Self-Efficacy Beliefs of Adolescents, vol. 5, ed. F Pajares and T Urdan, Greenwich, CT: Information Age, 307-337.

Bandura A, Locke EA (2003). Negative self-efficacy and goal effects revisited. J Appl Psychol 88, 87-99.

Barnes LLB, Harp D, Jung WS (2002). Reliability generalization of scores on the Spielberger State-Trait Anxiety Inventory. Educ Psychol Meas 62, 603-618.

Berman W (1984). Dissection dissected. Sci Teach 51, 42-49.

Bishop LJ, Nolen AL (2001). Animals in research and education: ethical issues. Kennedy Inst Ethics J 11, 91-112.

Boeckers A, Brinkmann A, Jerg-Bretzkec L, Lamp C, Traue HC, Boeckers TM (2010). How can we deal with mental distress in the dissection room? An evaluation of the need for psychological support. Ann Anat 192, 366-372.

Bye D, Pushkar D, Conway M (2007). Motivation, interest, and positive affect in traditional and nontraditional undergraduate students. Adult Educ Q 57, 141-158.

Casado MI, Castaño G, Arráez-Aybar LA (2012). Audiovisual material as educational innovation strategy to reduce anxiety response in students of human anatomy. Adv Health Sci Educ 17, 431-440.

Cassady JC, Johnson RE (2002). Cognitive test anxiety and academic performance. Cont Educ Psychol 27, 270-295.

Demirhan E (2014). Miracle or cruelty? The sophomore prospective science teachers' perspective of chicken embryonic development. Procedia Soc Behav Sci 152, 575-581.

DeRosa B (1986). Is dissection necessary? Child Anim 10, 1-2.
De Villiers R, Monk M (2005). The first cut is the deepest: reflections on the state of animal dissection in biology education. J Curric Stud 37, 583-600.

Gumora G, Arsenio WF (2002). Emotionality, emotion regulation, and school performance in middle school children. J School Psychol 40, 395-413.

Holstermann N, Grube D, Bögeholz S (2009). The influence of emotion on students' performance in dissection exercises. J Biol Educ 43, 164-168.

Horne DJ, Tiller JWG, Eizenberg N, Tashevska M, Biddle N (1990). Reactions of first year medical students to their initial encounter with a cadaver in the dissection room. Acad Med 65, 645-646.

Hoskins BB (1979). Sensitizing introductory biology students to biotech's issues. Am Biol Teach 41, 151-153.

Hug B (2008). Re-examining the practice of dissection: what does it teach? J Curric Stud 40, 91-105.

Hummel E, Randler C (2012). Living animals in the classroom-a meta-analysis on learning outcome and a treatment-control study focusing on knowledge and motivation. J Sci Educ Technol 21, 95105.

Igelstud D (1986). Frogs. Am Biol Teach 48, 435-436.

Jansen M, Scherer R, Schroeders U (2014). Students' self-concept and self-efficacy in the sciences: differential relations to antecedents and educational outcomes. Cont Educ Psychol 41, 13-24.

King LA, Ross CL, Stephens ML, Rowan AN (2004). Biology teachers' attitudes to dissection and alternatives. Altern Lab Anim 32, 475-484.

Kinzie MB, Strauss R, Foss J (1993). The effects of an interactive dissection simulation on the performance and achievement of high school biology students. J Res Sci Teach 30, 989-1000.

Kopec RH (2002). Virtual, on-line, frog dissection vs. conventional laboratory dissection: a comparison of student achievement and teacher perceptions among honors, general ability, and foundations-level high school biology classes. Doctoral dissertation, South Orange, NJ: Seton Hall University. ProQuest Dissertations and Theses Database (UMI No. 3040985).

Koutsis G, Panas M, Giogkaraki E, Potagas C, Karadima G, Sfagos C, Vassilopoulos D (2007). APOE $\varepsilon 4$ is associated with impaired verbal learning in patients with MS. Neurol 68, 546-549.

Krohne HW, Egloff B, Kohlmann CW, Tausch A (1996). Investigations with a German version of the Positive and Negative Affect Schedule (PANAS). Diagnostica 42, 139-156.

Lalley JP, Piotrowski PS, Battaglia B, Brophy K, Chugh K (2010). A comparison of V-Frog ${ }^{\oplus}$ to physical frog dissection. Int J Env Sci Educ 5, 189-200.

Lane J, Lan AM, Kyprianou A (2004). Self-efficacy, self-esteem and their impact on academic performance. Soc Behav Pers 32, 247-256.

Laux L, Glanzmann P, Schaffner P, Spielberger CD (1981). Das State-Trait-Angstinventar, Weinheim, Germany: Beltz.

Linnenbrink EA, Pintrich PR (2002). Motivation as an enabler for academic success. School Psychol Rev 31, 313-327.

Maloney R (2005). Exploring virtual fetal pig dissection as a learning tool for female high school biology students. Educ Res Eval 11, 591-603.

Marteau TM, Bekker H (1992). The development of a six-item shortform of the state scale of the Spielberger State-Trait Anxiety Inventory (STAI). Br J Clin Psychol 31, 301-306.

Montgomery L (2008). A comparison of the effectiveness of virtual and traditional dissection on learning frog anatomy in high school. Doctoral dissertation, Wilmington: University of Delaware, ProQuest Dissertations and Theses Database (UMI No. 3287762). 
National Association of Biology Teachers (2008). The Use of Animals in Biology Education. NABT Position Statements. www.nabt.org/ websites/institution/index.php?p=97 (accessed 10 January 2015).

National Science Teachers Association (2005). Responsible Use of Live Animals and Dissection in the Science Classroom. NSTA Position Statement. www.nsta.org/about/positions/animals.aspx.

Oakley J (2009). Under the knife: animal dissection as a contested school science activity. J Activist Sci Tech Educ 1, 59-67.

Offner S (1993). The importance of dissection in biology teaching. Am Biol Teach 55, 147-149.

Orlans FB (1988). Debating dissection. Sci Teach 55, 36-40.

Oyeyipo IP, Falana BA (2012). Attitude of preclinical students to cadaver dissection in a southwest Nigerian medical school. Int J Trop Med 7, 1-5.

Pajares F (2002). Gender and perceived self-efficacy in self-regulated learning. Theory Into Practice 41, 116-225.

Pekrun R, Götz T, Frenzel AC, Barchfeld P, Perry RP (2011). Measuring emotions in students' learning and performance: the Achievement Emotions Questionnaire (AEQ). Contemp Educ Psychol 36, 36-48.

Pekrun R, Götz T, Titz W, Perry RP (2002). Academic emotions in students' self-regulated learning and achievement: a program of qualitative and quantitative research. Educ Psychol 37, 91-105.

People for the Ethical Treatment of Animals (2004). How Animals Are Collected and Killed for Dissection and the Alternatives You Can Choose: The PETA Guide to Animals and the Dissection Industry, Norfolk, VA.

Pintrich PR, De Groot EV (1990). Motivational and self-regulated learning components of classroom academic performance. J Educ Psychol 82, 33.

Randler C, Hummel E, Prokop P (2012a). Practical work at school reduces disgust and fear of unpopular animals. Soc Anim 20,61-74.

Randler C, Hummel E, Wüst-Ackermann P (2013). The influence of perceived disgust on students' motivation and achievement. Int J Sci Educ 35, 2839-2856.
Randler C, Ilg A, Kern J (2005). Cognitive and emotional evaluation of an amphibian conservation program for elementary school students. J Env Educ 37, 43-52.

Randler C, Wüst-Ackermann P, Otte im Kampe V, Meyer-Ahrens IH, Tempel BJ, Vollmer C (2016). Effects of expressive writing effects on disgust and anxiety in a subsequent dissection. Res Sci Educ (in press).

Randler C, Wüst-Ackermann P, Vollmer C, Hummel E (2012b). The relationship between disgust, state-anxiety and motivation during a dissection task. Learn Individ Diff 22, 419-424.

Rossi V, Pourtois G (2012). Transient state-dependent fluctuations in anxiety measured using STAI, POMS, PANAS or VAS: a comparative review. Anx Stress Cop 25, 603-645.

Spielberger CD, Anton WD, Bedell J (1976). The nature and treatment of test anxiety. In: Emotions and Anxiety: New Concepts, Methods, and Applications, ed. M Zuckerman and CD Spielberger, Hillsdale, NJ: Erlbaum, 317-344.

Spielberger CD, Gorsuch RL, Lushene RE (1970). Manual for the State-Trait Anxiety Inventory (Self-Evaluation Questionnaire), Palo Alto, CA: Consulting Psychologists Press.

Thompson ER (2007). Development and validation of an internationally reliable short-form of the positive and negative affect schedule (PANAS). J Cross Cult Psychol 38, 227-242.

Watson D, Clark LA (1984). Negative affectivity: the disposition to experience aversive emotional states. Psychol Bull 96, 465-490.

Watson D, Clark LA, Tellegen A (1988). Development and validation of brief measures of positive and negative affect: the PANAS scales. J Pers Soc Psychol 54, 1063-1070.

Williams AD, Greenwald EE, Soricelli RL, DePace DM (2014). Medical students' reactions to anatomic dissection and the phenomenon of cadaver naming. Anat Sci Educ 7, 169-180.

Youngblut C (2001). Use of multimedia technology to provide solutions to existing curriculum problems: virtual frog dissection. Doctoral dissertation. Fairfax, VA: George Mason University. ProQuest Dissertations and Theses Database (UMI No. 3008579). 